RJOAS, 2(110), February 2021

DOI https://doi.org/10.18551/rjoas.2021-02.08

\title{
DETERMINANTS OF CAPITAL EXPENDITURE AND ITS EFFECT ON REGIONAL FINANCIAL PERFORMANCE: A STUDY ON DISTRICT AND CITY IN WEST NUSA TENGGARA PROVINCE OF INDONESIA
}

\author{
Putra Ardiansyah Fajar Susila* \\ Master's Program in Accounting, Faculty of Business and Economics, University of Mataram, \\ Indonesia
}

Irwan M., Husnan Lalu Hamdani, Lecturers

Faculty of Business and Economics, University of Mataram, Indonesia

*E-mail: ardianfsp@gmail.com

\begin{abstract}
The purpose of this study is to test and provide empirical evidence regarding the effect of regional revenue (PAD), balance funds (DP) and excess budget financing (SiLPA) on capital expenditure and to see how capital expenditure affects a regional financial performance. Tests were carried out in 10 districts and cities on NTB Province using Financial Report data from 2012 to 2018 using Partial Least Square (PLS) analysis. The results showed that PAD had a significant and positive effect on capital spending, while DP and SiLPA had no effect on capital spending. This shows that the district and city governments on NTB Province have made maximum use of PAD in realizing their capital expenditures, whereas the local governments have not been able to maximize the balance funds that sourced from the Central Government and SiLPA in realization a number of capital expenditures. The results of this study are expected to be able to provide an overview of how district and city governments in NTB Province manage local revenue both PAD and balance funds to realize capital expenditures that directly impact government services to the community and this research can be taken into consideration in assessing regional financial performance by principals (society) against its agent (government).
\end{abstract}

\section{KEY WORDS}

Local own revenue, intergovernmental revenue, capital expenditure, financial performance.

The problem faced by local governments in public sector organizations is the allocation of budgets. Budget allocation is the amount of fund allocated for each program. With limited resources, the Regional Government must be able to allocate the revenues obtained for regional expenditures that are productive. Regional expenditure is an estimate of the burden of regional expenditure which is allocated fairly and evenly so that it can relatively be enjoyed by all groups of society without discrimination, especially in the provision of public services (Halim, 2007).

So far, local governments have mostly used regional revenues for operating expenditures rather than capital expenditures. Operational expenditure is regional government expenditure which consists of personnel expenditure, goods and services expenditure, interest expenditure, subsidy expenditure, and grant expenditure. In terms of benefits, budget allocation for the capital expenditure sector is very beneficial and productive in providing services to the public. Improving the quality of public services can be improved through improving service quality management, namely efforts to minimize the gap between service levels and consumer expectations (Bastian, 2006). 
Capital expenditure is a component of direct expenditure in the government budget which produces output in the form of fixed assets. Capital expenditures are generally allocated to be used as a means of regional development, such as the development and improvement of the education, health and transportation sectors, so that people can enjoy the benefits of regional development. (Mardiasmo, 2013) said that normatively the higher the level of capital investment is expected to be able to increase the level of public participation in development. Increasing capital expenditure is one way of increasing economic growth in a region, through local government capital spending to build public facilities and improve the quality of public services. (Widiasih and Gayatri, 2017) The preparation of regional government capital expenditures, ideally, uses a public investment policy system, which is based on economic reasonableness, efficiency and effectiveness (value for money).

According to Sucipto (2007), regional financial performance is the level of achievement of a work result in the regional financial sector which includes regional revenues and expenditures using financial indicators that are determined through a policy or statutory provision during one budget period. One of the tools to analyze the financial performance of local governments is to analyze the financial ratios of the Regional Revenue and Expenditure Budget (APBD) that have been determined and implemented (Halim, 2007), such as the ratio of regional financial independence (fiscal autonomy), effectiveness ratio and efficiency ratio of regional finance.

The Regional Original Income (PAD) collected by the Regional Government significantly affects the realization of Capital Expenditures, this is stated in research conducted by Tuasikal (2008), Subowo and Wati (2010), Kurniawan (2013), Sholikhah and Wahyudin (2014), Mayasari et al. (2014), Rully Farel (2015), Anjani et al. (2015), Ranti Suryana (2017). On a different side, a study from Oktora and Pontoh (2013) found a low correlation between PAD and capital expenditure due to a lack of proportion of PAD in local government revenue. Several studies that support the weak relationship between PAD and local government capital expenditures include studies by Abdulah and Halim (2006), Paujiah (2010), and Wandira (2013).

Research conducted by Abdullah and Halim (2006), Subowo and Wati (2010) shows that there is an effect of Balancing Funds provided by the Central Government on the Realization of Regional Government Capital Expenditures. Studi Oktora and Pontoh (2013) see a close relationship between DAU which is one component of the balance funds and capital expenditures. However, a study by Sholikhah and Wahyudin (2014) found that DAU did not affect capital spending.

Ardhini (2011) examines the relationship between SLIP and capital expenditures with research locations in districts / cities in the Central Java region. The results of his research indicate that SiLPA has a positive effect on capital spending. In line with Ardhini, research conducted by Kusnandar and Siswantoro (2012), Rully Farel (2015) and Ranti Suryana (2015) shows that there is a significant positive relationship with SILPA on capital expenditure.

Capital expenditures that reflect the development of infrastructure and infrastructure built by the Regional Government are expected to be able to improve the performance of regional finances. Sugiono (2014) and Anjani et al. (2015) looked at the significant and positive effects of capital expenditures on regional government financial performance. However, the research of Solomon (2013) and Nugroho (2012) found that capital expenditure has no effect on the financial performance of the Regional Government. Darsono (2013) found that capital expenditure has an insignificant positive effect on the financial performance of the Regional Government. Other research from Imawan and Wahyudin (2014) and Darwis (2015) found that capital spending has a negative effect on regional financial performance. The difference in the results of these studies makes the opportunity for further research to be carried out more interestingly, especially in districts and cities in NTB Province which are developing areas so that the results of this study can be used as a reference point in implementing regional government spending quality, especially for capital expenditures and their influence on regional financial performance in terms of accelerating development in NTB Province, Indonesia. 


\section{HYPOTHESIS DEVELOPMENT}

In the process of determining revenue targets and allocating resources in the area of expenditure, agency problems are always subject to agency problems. The community, which in its role as the principal, gives regulatory authority and provides resources to the government, which acts as an agent to continue to increase regional revenue. Local governments as the agency should provide reciprocal improvements in public infrastructure, facilities and infrastructure that can improve the quality of public services.

The increase in PAD is expected to increase regional government investment in capital expenditures, so that the quality of public services will improve. The Regional Original Income (PAD) collected by the Regional Government significantly affects the realization of capital expenditures, this is stated in research conducted by Tuasikal (2008), Subowo and Wati (2010), Kurniawan (2013), Sholikhah and Wahyudin (2014), Mayasari et al. (2014), Rully Farel (2015), Anjani et al. (2015), Ranti Suryana (2017).

Thus, the researcher formulated the following hypothesis: $\mathrm{H} 1=$ local revenue has a positive effect on capital expenditure.

In carrying out agency relations between the community and regional governments, namely improving the quality of public services, regional governments do not only rely on PAD alone. Research conducted by Abdullah and Halim (2006), Subowo and Wati (2010) shows that there is an effect of balancing funds provided by the central government on the realization of regional government capital expenditures for a long time, but in reality there are regional and regional government capital expenditures, which still depend on regional government funding sources on the balance fund (transfer funds from the central government).

Based on the description of the theory, the researcher formulates the following hypothesis: $\mathrm{H} 2$ = Balanced Fund has a positive effect on capital expenditure.

In Permendagri number 13 of 2006, Remaining Budget Financing, hereinafter abbreviated as SiLPA, is the excess of realized budget revenues and expenditures during one budget period which can later be used in the following year. Ardhini (2011) in his research results show that SiLPA has a positive effect on capital expenditure. In line with Ardhini, research conducted by Kusnandar and Siswantoro (2012), Rully Farel (2015) and Ranti Suryana (2017) shows that there is a significant positive relationship with SiLPA on capital spending. Such conditions provide information that SiLPA is one of the sources of capital expenditure funding.

Based on the description of the theory, the researcher formulates the following hypothesis: $\mathrm{H} 3$ = SiLPA has a positive effect on capital expenditure.

The community needs to exercise control over the allocation of expenditure which is carried out by the government in terms of being represented by the legislature. One of the ways to control it is by assessing the government's financial performance. Efficient, effective and economical violation is a reflection of the performance of regional finance.

Capital expenditures that reflect the development of infrastructure and infrastructure built by the Regional Government are expected to be able to improve regional financial performance. Sugiono (2014), Imawan and Wahyudin (2014), Darwis (2015) and Anjani et al. (2015) looked at the effect of capital spending on regional government financial performance.

With the above explanation, the researcher formulated the following hypothesis: H4 = Capital Expenditures Have a Positive Effect on Regional Financial Performance.

\section{METHODS OF RESEARCH}

This research uses the population of all regencies and cities in West Nusa Tenggara Province with a time horizon from 2012 to 2018. This research technique uses the census method which is the method by taking population. The population used is 10 districts / cities in West Nusa Tenggara Province with a time horizon used in 2012 - 2018. 
Capital expenditure in this research is measured using the realization of land expenditure; equipment and machinery; buildings and structures; roads, irrigation and networks; and other assets in the reports on realization of districts and cities in NTB in 2012-2018.

Regional financial performance is the level of achievement of regional government by using financial indicators. The regional financial performance in this study was measured by 3 indicators, namely: Ratio of Independence, Efficiency Ratio, and Effectiveness ratio

In this study, regional revenues were measured using the realization of regional taxes; regional retribution; the results of the management of separated regional assets; and other legal regional revenues in the reports on the realization of the regencies and cities in NTB in 20122018.

The balance funds in this research will be measured using the reports on the realization of the counties and cities in NTB in 2012-2018 in the tax revenue account; general allocation funds; and special allocation funds.

SiLPA is an indicator of efficiency, because SiLPA will only be formed if there is a surplus in the APBD and at the same time there is a positive net financing, where the revenue component is greater than the financing expenditure component.

This study uses partial regression analysis (Partial Least Square / PLS) to test the six hypotheses proposed in this study. The choice of the PLS method was based on the consideration that in this study there were two bound (endogenous) variables.

The structure and measurement models are shown in the following figure:

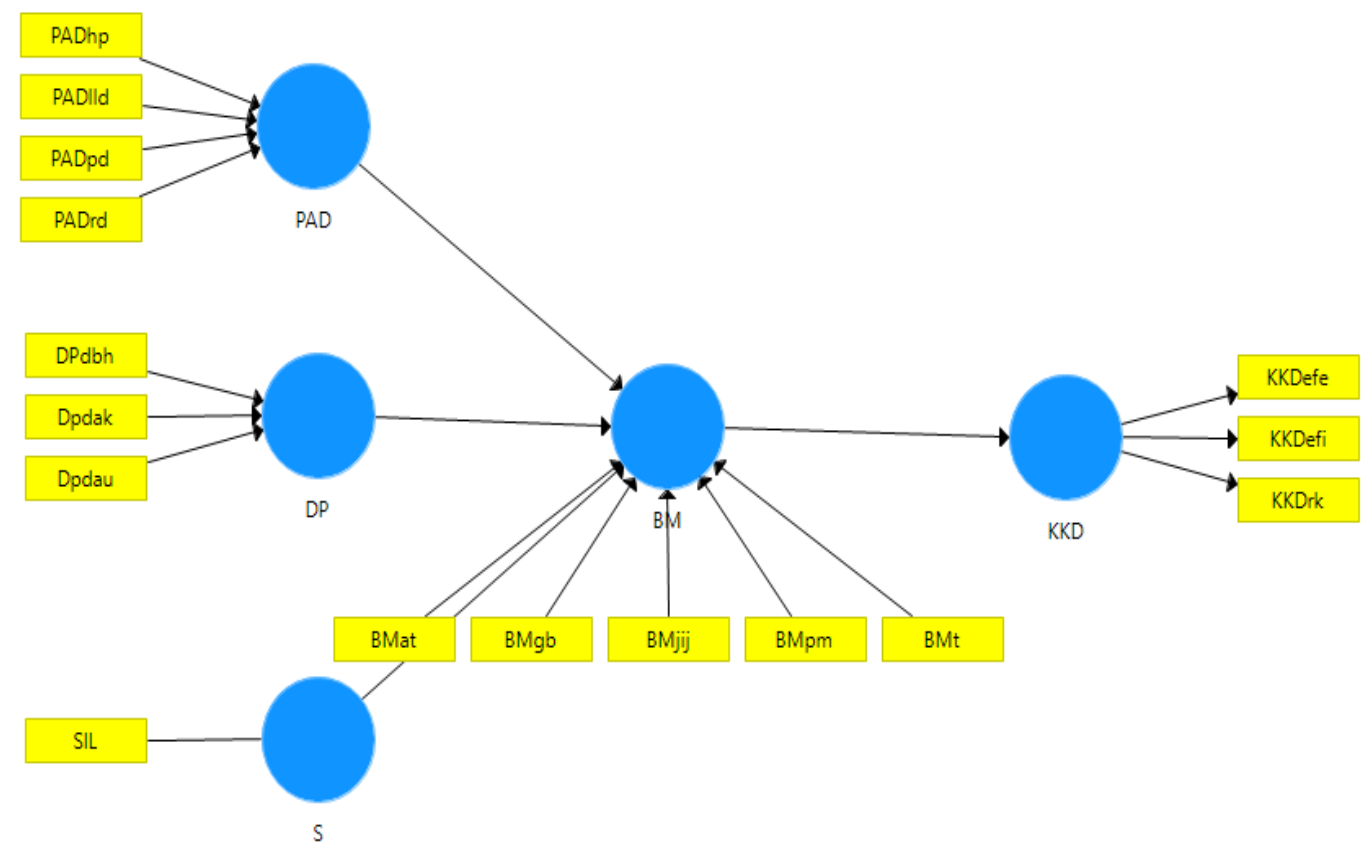

Figure 1 - Structure and measurement model

Note: $\mathrm{PAD}=$ Regional Original Income; $\mathrm{DP}=$ Balancing Fund; $\mathrm{S}=$ Remaining Budget Financing; $\mathrm{BM}=$ Capital Expenditure; $\mathrm{KKD}=$ Regional Financial Performance; $\beta=$ Beta, the coefficient of influence of endogenous variables on endogenous variables; $\gamma=$ Gamma, the coefficient of the influence of exogenous variables on endogenous variables; $\zeta=$ Zeta, model error; $\delta=$ Delta, formative indicator measurement error; $\varepsilon=$ Epsilon, reflective indicator measurement error.

\section{RESULTS AND DISCUSSION}

Convergent validity is used as a measure to see the positive relationship between indicators on one construct (variable). The required loading factor value is 0.7 . Results of the 
default PLS Algorithm from this study showed the coefficients of KKDefi and KKDef did not meet the validity requirements of the performance constructs of the regional finance. The results of re-estimating the model after removing the KKDefi and KKDefeters are shown in the following figure.

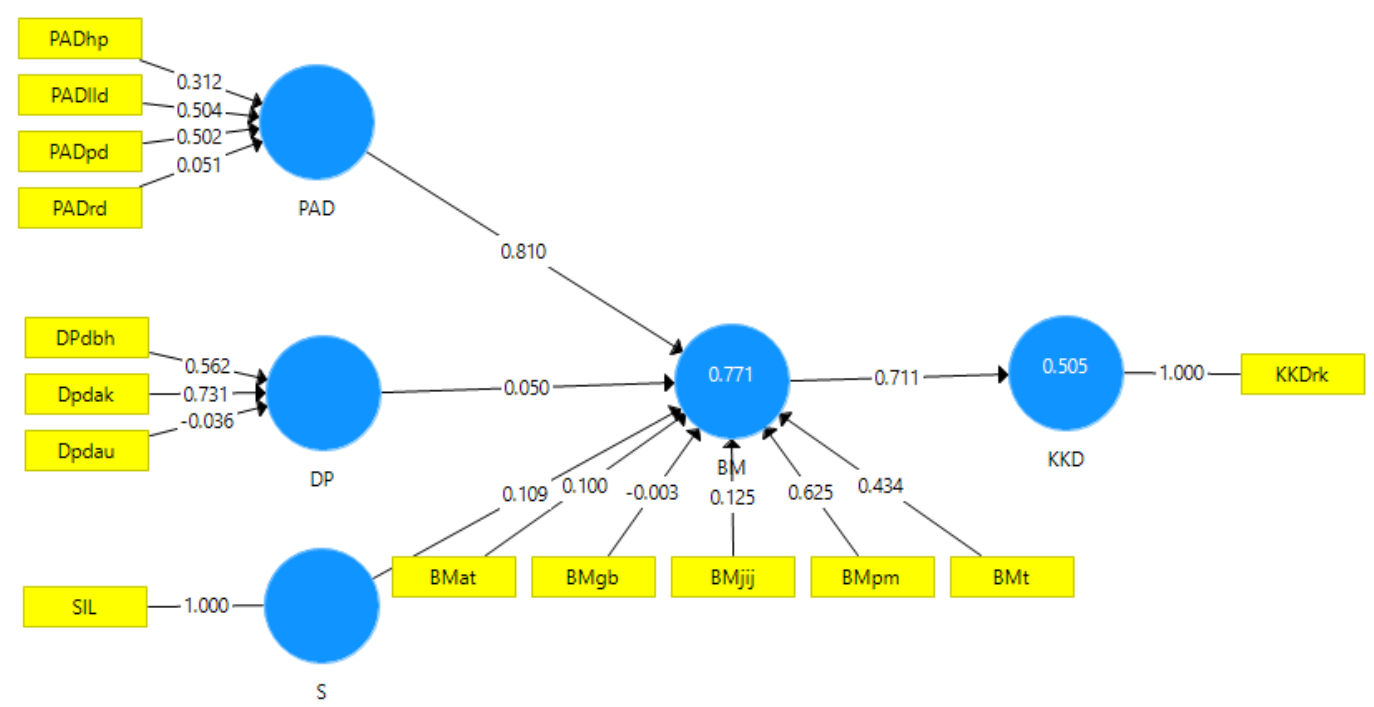

Figure 2 - Re-estimate PLS Algorithm Results (Source: PLS 3.0, data processed, 2020)

Based on these figure, it can be seen that the loading factor for the KKD indicator is 1 so that it can be stated that the KKD construct has met the convergent validity because the loading factor is $>0.7$. The test results show that the $R 2$ value of the PLS Algorithm calculation results is as follows.

Table 1 - R Square (Source: PLS 3.0, data processed, 2020)

\begin{tabular}{|l|r|}
\hline & R Square \\
\hline BM & 0.771 \\
\hline KKD & 0.505 \\
\hline
\end{tabular}

Based on table above, it is known that the construct of capital expenditure (BM) can be explained by the construct variables of regional income (PAD), balance funds (DP) and SiLPA (S) of $77.1 \%$ and for the construction of regional financial performance (KKD) it can be explained by the BM construct of $50.5 \%$.

Changes in the determinant coefficient value (R2) when a specific construct is removed from the model can be used to evaluate whether the construct has an additive effect on the endogenous construct (Hair et al., 2014).

Table 2 - Effect Size f2 (Source: PLS 3.0, data processed, 2020)

\begin{tabular}{|c|c|c|}
\hline Variable relationship & f Square Value & Goodness of Model \\
\hline $\mathrm{DP}>\mathrm{BM}$ & 0.007 & Small \\
\hline $\mathrm{PAD}>\mathrm{BM}$ & 1.731 & Big \\
\hline $\mathrm{S}>\mathrm{BM}$ & $0 ; 047$ & Middle \\
\hline
\end{tabular}

Measure the significance of the hypothesis support by comparing the $p$-value with the alpha value. 
Table 3 - Path Coefficients (Source: PLS 3.0, data processed, 2020)

\begin{tabular}{|l|r|r|r|r|r|}
\hline & $\begin{array}{c}\text { Original } \\
\text { Sample (O) }\end{array}$ & $\begin{array}{c}\text { Sample } \\
\text { Mean (M) }\end{array}$ & $\begin{array}{c}\text { Standard } \\
\text { Deviation } \\
\text { (STDEV) }\end{array}$ & $\begin{array}{c}\text { T Statistics } \\
(\text { (O/STDEV) }\end{array}$ & P Values \\
\hline BM -> KKD & 0.711 & 0.711 & 0.095 & 7.470 & $\mathbf{0 . 0 0 0}$ \\
\hline DP -> BM & 0.050 & 0.073 & 0.115 & 0.437 & $\mathbf{0 . 6 6 2}$ \\
\hline PAD -> BM & 0.810 & 0.811 & 0.094 & 8.581 & $\mathbf{0 . 0 0 0}$ \\
\hline S -> BM & 0.109 & 0.088 & 0.073 & 1.488 & $\mathbf{0 . 1 3 7}$ \\
\hline
\end{tabular}

Based on table above, there are accepted alternative hypotheses, namely $\mathrm{H} 1$ and $\mathrm{H} 4$. Two alternative hypotheses were rejected, namely $\mathrm{H} 2$ and $\mathrm{H} 3$, at a significance level of $\alpha=5 \%$ (one tailed).

The results of testing on the first hypothesis in this study show that the opinion of regional heat has a significant positive effect on the capital expenditure variables in the 2012-2018 study period in the district and municipal governments of NTB Province. This shows that regional governments use regional revenue to increase the realization of capital expenditures. The results of this study support and are in line with the research results of Tuasikal (2008), Subowo and Wati (2010), Kurniawan (2013), Sholikhah and Wahyudin (2014), Mayasari et al. (2014), Rully Farel (2015), Anjani et al. (2015), Ranti Suryana (2017) who saw that regional income has a significant positive effect on capital spending. On the other hand, the results of this study are not in line with the research conducted by Oktora and Pontoh (2013) who found a low correlation between PAD and capital expenditure due to less proportion of PAD in regional income. Other studies that show a low relationship between PAD and capital expenditure are found in studies by Abdulah and Halim (2006), Paujiah (2010) and Wandira (2013).

Despite the government's PAD contribution $d$ area is still very small in terms of regional income during the observation period, on average, it is at $10.33 \%$ with the lowest contribution in 2012 in Bima City 2.47\% and the highest in Mataram City by $27.17 \%$ in 2017, but PAD is the source of income from the area of ownership and ownership of the area of ownership and ownership.

The test results on the second hypothesis show that the balancing funds do not significantly affect capital expenditures in Regency and City Governments in NTB Province. The results of this study indicate that, although the balance funds of the Regency and City Governments in the Province of NTB have a very high contribution to the regional income, on average it reaches $71.98 \%$, it has not been able to be maximally utilized for capital expenditures. This is due to the fact that the balance funds are funds from the central government, so that their use must be in accordance with the mandate of the balance funds alone so that the regional governments do not fully have the freedom to manage the balance funds to increase regional capital expenditures.

The results of this study are not in line with research conducted by Abdullah and Halim (2006) and Subowo and Wati's (2010) research which found a significant relationship between balance funds and capital expenditures. The results of this study found that regional governments in their capital expenditures tend to use the balance funds obtained from the central government rather than using the revenue generated from local government sources in the region in terms of regional local government revenue (PAD). However, research conducted by Anjani et al. (2015) show that balancing funds have no significant effect on capital spending in regional governments (balancing funds are not the determinants of capital expenditures).

The results of the third hypothesis show that the SiLPA (S) of Regency and City Governments in NTB Province does not significantly affect capital expenditures. This indicates that the mandatory amount of SiLPA does not affect regional government capital spending.

The results of this study are not in line with research conducted by Ardhini (2011), Kusnandar and Siswantoro (2012) and research by Rully Farel (2015) where there is a 
significant positive relationship between SiLPA and capital expenditure. These conditions indicate that SiLPA is one of the sources of funding for regional government capital expenditures.

For the results of testing the fourth hypothesis, it shows that the capital expenditures of the Regency and City governments in the Province of NTB during the observation period can affect the performance of regional finance (KKD). Local government KKD in this study measured with an independent democracy provides evidence that high capital expenditures on facilities and infrastructure related to public interests can increase the independence of regencies and municipalities in NTB Province. This shows that the realization of capital expenditures that are directly related to the interests of the public and the community can carry out activities or economic activities to the maximum extent.

The results of this study were collaborative with research conducted by Sugiono (2014) and Anjani et al. (2015) who saw the effect of capital spending on regional government financial performance positively and significantly. This research is not in line with the research conducted by Darsono (2013) who found that capital expenditure has a negative effect on the performance of regional finance.

The results of this study have three implications, namely theoretical, practical and policy implications. The theoretical implications of this research prove that in the theory of agency in the public sector, especially those related to budgeting and the actual realization are related to the interests of the agency and the principal so that there is no overall revenue allocation for areas that can be allocated as a whole to the areas that touch the immediate public interests.

From practical implications, this study shows that regional income gain is a determining factor of capital expenditures and capital expenditures have an influence on the performance of regional finances which in this study was measured by self-reliance. From the policy aspect, regional governments must continue to discover the potential revenue from areas that have not been properly managed so that the revenue from the regions can increase every year. Regional governments must also improve regulations related to regional revenue and regulations related to capital expenditures that are prioritized by regional governments, especially those related to community service.

\section{CONCLUSION}

The results of this study indicate that regional opinion has a significant positive effect on capital expenditures in district and municipal governments in the 2012-2018 periods. This shows that PAD is a determining factor for capital expenditures. In the future, it is hoped that the Regency and City governments in NTB Province can continue to increase PAD and use it more in the capital expenditure sector.

The balance fund does not affect capital expenditures. This indicates that the use of balancing funds by the Regency and City governments in NTB Province is mostly used for other expenses besides capital expenditures. In addition, the Regency and City governments in NTB Province have not optimally utilized the revenues from these central governments for capital expenditures.

SiLPA (S) District and City Governments in NTB Province do not significantly affect capital expenditures. This indicates that the mandatory amount of SiLPA does not affect regional government capital spending.

Capital expenditures realized by the District and City Governments in NTB Province during the 2012-2018 period had a significant positive effect on the regional financial performance as measured by independence. This shows that the high capital expenditure realized is also the highest regional financial performance in terms of increasing regional selfreliance. 
This study has limitations that can be fixed in future studies. Limitations in this study include that this study has not included non-financial variables in predicting their effect on capital expenditure. The scope of this research is only carried out at the district and city governments in the Province of NTB, so that the general results and recommendations of this research are less applicable to regency and city governments in other provinces.

Regional financial performance which initially uses three features of independence, efficiency ratios, and effectiveness ratios as indicators but only self-reliance factors that fulfill the loading factor. Future research is expected to use other ratios to predict the relationship between capital spending and regional financial performance.

\section{REFERENCES}

1. Abdullah, S., and A.Halim. 2006. Studiatas Belanja Modalpada Anggaran Pemerintah Daerah dalam Hubungannyadengan Belanja Pemeliharaan and Sumber Pendapatan. Jurnal Akuntansi Pemerintah, 2 (2):17-32.

2. Akai, N. and Sakata, M. 2002. Fiscal Decentralization Contributes to Economic Growth: Evidence form State-Level Cross-Section Data for the United States. Journal of Urban Economics, Vol.52, pp: 93-108.

3. Alamri, Rosa. 2015. Pengaruh Pajak Daerah, Retribusi Daerah, Hasil PPengelolaan Kekayaan Darah yang Dipisahkan and Lain-lain Pendapatan Asli Daerah yang Sah terhadap Belanja Daerah (Studi Kasus Kabupaten-Kota Di Provinsi Gorontalo). Jurnal Akuntansi Universitas Negeri Gorontalo.

4. Aramana, Desi. 2011. Pengaruh Pendapadatan Asli Daerah, Dana Perimbangan and LainLain Pendapatan Daerah Yang Sah terhadap Belanja Daerah dengan Kinerja Keuangan Pemerintah Daerah sebagai variabel moderating pada Provinsi Sumatera Utara. Tesis, Universitas Sumatera Utara, Medan.

5. Bastian, Indra. 2016. AkuntansiSektorPublik:SuatuPengantar. Jakarta:Erlangga.

6. Darmayasa, I.N., and I. K. Suandi. 2014. FaktorPenentuAlokasiBelanja Modal dalam APBD Pemerintah Provinsi. Simposium Nasional Akuntansi Mataram 24-27 September2014.

7. Darsono, I.L. 2013. Pengaruh Alokasi Belanja Modal and Pendapatan Asli Daerahterhadap Kemandirian Keuangan Pemerintah Daerah. Jurnal Profita: Kajian IImu Akuntansi, 1(8):1121.

8. Ghamkar, Shama and Wallace Oates. 1996. Asymetries in the Response to Increases and Decreases in Governmental Grants: Some Empirical Evidence. National Tax Journal, pp: 510-512.

9. Ghozali, Imam. 2013. AplikasiAnalisis Multivariate dengan Program SPSS 21. Semarang: Badan Penerbit Universitas Diponegoro.

10. Hair, et al. 2014. A Primer on Partial Least Square Structural Equation Modeling (PLSSEM). SAGE Publications, Inc. California. USA

11. Halim, Abdul. 2001. Bunga Rampai: Manajemen Keuangan Daerah. Edisi Pertama. Yogyakarta: UPP AMP YKPN.

12. Halim, A. 2002. Akuntansi Sektor Publik: Akuntansi Keuangan Daerah. Jakarta: Salemba Empat.

13. Harianto, David and Priyo Hari Adi. 2007. Hubungan Antara Dana Alokasi Umum, Belanja Modal, Pendapatan Asli Daerah and Pendapatan Per Kapita. Paper disajikan pada Simposium Nasional Akuntansi X, Makasar.

14. Harjiyanti, Nur. 2015. Pengaruh Produk Domestik Regional Bruto, Pendapatan Asli Daerah, Dana Alokasi Umum and Dana Alokasi Khusus terhadap Belanja Daerah (Studi Kasus di Daerah Istimewa Yogyakarta Tahun 2007-2013). Jurnal Akuntansi. Universitas PGRI Yogyakarta. 
15. Hayek, Friedrich. 1945. The Use of Knowledge in Society. American Economic Review, 35, pp: 519-530.

16. Hewitt, Daniel and Dennis R. Heffley. 1989. Unfolding the Flypaper: The Effects of Intergovernmental Grants in an Open Local Economy. IMF Working Paper No. 89/58.

17. Holtz-Eakin, Douglas, Harvey S. Rosen and Schuyler Tilly. 1985. Intertemporal Analysis of State an Local Government Spending: Theory and Test. Journal of Urban Economics.

18. Imawan, R., and A. Wahyudin. 2014. Analisis Kemandirian Keuangan Daerah Provinsi Jawa Tengah Tahun Anggaran 2010-2012. Accounting Analysis Journal. 3 (2):147-155.

19. Kuncoro, Mudrajad. 2004. Otonomi \& Pembangunan Daerah. Jakarta: Erlangga.

20. Kurniawan, A. 2013. Pengaruh Pertumbuhan Ekonomi, Pendapatan Asli Daerah, Dana Bagi Hasil, Dana Alokasi Umum and Dana Alokasi Khususterhadap Anggaran Belanja Modal pada Pemerintah Kabupaten/Kota se-Provinsi Lampung. Tesis. Universitas Lampung.

21. Maggi, Eva Maria and Ladurner, Ulrich. 2009. Federal Features and Financial Decentralization. Inhouse Seminar. Eurac Research.

22. Mardiasmo. 2013. Pengukuran Kinerja SektorPublik. Yogyakarta: BPFE Yogyakarta.

23. Mayasari,L.P.R.,N.K.Sinarwati., and G.A.Yuniarta. 2014. Pengaruh Pertumbuhan Ekonomi, Pendapatan Asli Daerah and Dana Alokasi Umumterhadap Pengalokasian Anggaran Belanja Modal pada Pemerintah Kabupaten Buleleng. E-Jurnal S1 AK Universitas Pendidikan Ganesha,2 (1).

24. Nagathan and K. J. Sivagnanan. 1999. Federal Transfer and Tax Effort of States in India. Indian Economic Journal.

25. Nahlia, Fera. 2014. Flypaper Effect pada Pendapatan Asli Daerah, Dana Alokasi Umum, and Dana Alokasi Khusus terhadap Belanja Daerah pada Kabupaten / Kota di Provinsi Kepulauan Riau Periode 2007-2012. Jurnal Universitas Maritim Raja Ali Haji.

26. Nugroho, F. 2012. PengaruhBelanja Modal Terhadap Kinerja Keuangan Daerah denganPendapatan Asli Daerah sebagaiVariabel Intervening. Diponegoro Journal of Accounting, 1 (2):1-14.

27. Oktora, F.E., and W. Pontoh. 2013. Analisa Hubungan Pendapatan Asli Daerah, Dana AlokasiUmum, and Dana Alokasi Khususatas Belanja Modal pada Pemerintah Daerah Kabupaten Tolitoli Provinsi Sulawesi Tengah. Jurnal Accountanility, 2 (2):1-10

28. Paujiah, S.P. 2010. PengaruhPendapatan Asli Daerah (PAD) and Dana Alokasi Umum(DAU) terhadapBelanja Modal (Studi Kasus pada Pemerintah Kota Tasikmalaya). journal.unsil.ac.id/download.php?id=367.

29. Purbayu, Budi Santosa. 2005. Analisis Pendapatan Asli Daerah (PAD) and Faktor- Faktor Yang Mempengaruhinya dalam Upaya Pelaksanaan Otonomi Daerah di Kabupaten Kediri. Jurnal Dinamika Pembangunan, Vol.2, No.1, Ilmu Ekonomi Studi Pembangunan Fakultas Ekonomi Universitas Diponegoro, Semarang.

30. Putra, Ida Bagus Dwi. 2015. Dana Alokasi Umum, Dana Alokasi Khusus, Dana Bagi Hasil and Pendapatan Asli Daerah Provinsi Bali. E Journal Akuntansi Universitas Udayana, Vol. 13.3 Desember (2015).

31. Rizki I. P., Arda. 2015. Pengaruh Pendapatan Asli Daerah (PAD), Dana Alokasi Umum (DAU), Dana Bagi Hasil (DBH) and Dana Alokasi Khusus (DAK) terhadap Belanja Daerah. (Studi Kasus pada Pemerintahan Provinsi Jawa Barat). Skripsi. Telkom University, Bandung.

32. Rusydi, Bahrul Ulum. 2010. Analisis Determinan Kinerja Keuangan Pemerintah Daerah and Deteksi Ilusi Fiskal (Studi Kasus Provinsi di Indonesia tahun 2005-2008). Skripsi. Fakultas Ekonomi Universitas Diponegoro, Semarang.

33. Setiawan, Dian. 2012. Pengaruh Pendapatan Asli Daerah and Dana Bagi Hasil terhadap Belanja Daerah (Studi Kasus pada Pemerintah Kota Bandung). Skripsi. Fakultas Ekonomi Universitas Komputer Indonesia. 
34. Siregar, Hara Rizky. 2012. Analisis Determinan and Deteksi llusi Fiskal pada Kinerja Keuangan Pemerintah Kabupaten/Kota Se-Sumatera Utara. Tesis. Sekolah Pascasarjana Universitas Sumatera Utara, Medan.

35. Sholikhah, I., Wahyudin A., 2014. Analisa Belanja Modalpada Pemerintah Kabupaten / Kotadi Jawa. Accounting Analysis Journal 3(4):553-562.

36. Simanullang, G. 2013. PengaruhBelanja Modal, Intergovermental Revenue and Pendapatan Asli Daerah terhadap Kinerja Keuangan Daerah Kota and Kabupaten di Provinsi Kepulauan Riautahun 2008-2012. Umrah Journal of Accounting 1(1):1-24.

37. Sucipto. 2007. Penilaian Kinerja Keuangan Jurnal Akuntansi Universitas Sumatra Utara. Medan.

38. Subowo and E.R. Wati. 2010. Hubunganantara PAD and Dana Perimbangandengan Belanja Modal Pemda Kudus. Jurnal Dinamika Akuntansi, 2 (2):73-82.

39. Sugiyono. 2013. Metode Penelitian Bisnis Pendekatan Kuantitatif, Kualitatif and R\&D. Bandung: ALFABETA.

40. Sugiono, S. 2014. Pengaruh Moderasi Pendapatan Asli Daerahterhadap Hubungan Belanja Modal and Kemandirian Keuangan Daerah. Jurnal Akuntansi Unesa, 2 (3):1-27.

41. Tiebout, Charles M. 1956. A Pure Theory of Local Expenditures. Journal of Political Economy, 64(5), pp: 416-424.

42. Tanzi, Vito. 1972. Tax Payer Choice in Future Tax Shifts. Tax Review. Vol. XXXIII, No.11, pp: $75-88$.

43. Tuasikal, A. 2008. Pengaruh DAU, DAK, PAD, and PDRB terhadap Belanja Modal Pemerintah Daerah Kabupaten/Kota Di Indonesia. Universitas Pattimura Ambon. Jurnal Telaah and Riset Akuntansi, 1 (2):142-155

44. Yunus, Ririn A., 2015. Pengaruh Dana Perimbangan and Produk Domestik Regional Bruto terhadap Belanja Daerah di Kabupaten Bone Bolango Tahun 2009-2013. Jurnal Akuntansi Universitas Negeri Gorontalo.

45. Wandira, A.G. 2013. Pengaruh PAD, DAU, DAK, and DBH Terhadap Pengalokasian Belanja Modal. Accounting Analysis Journal, 2 (1):44-51.

46. Widiasih, Ni Nyoman and Gayatri. 2017. Pengaruh Pendapatan Asli Daerah, Dana AlokasiUmum, and Dana Bagi Hasil Pada Belanja Modal. E-Jurnal Akuntasi Vol 18 No. 3 (2017).

47. Electronic Source: www.djpk.kemenkeu.go.id.

48. Electronic Source: www.ntbprov.go.id. 